\title{
Homer's Odyssey: From Classical Poetry to Threshold Graphic Narratives for Dual Readership
}

\author{
La Odisea de Homero: desde la poesía clásica hasta las narrativas \\ gráficas para lectores duales
}
L'Odissea d'Homer: des de la poesia clàssica fins les narratives gràfiques per a lectors duals

\author{
Evangelia Moula. National and Kapodistrian University of Athens, Greece. \\ moulaevang@gmail.com \\ https://orcid.org/0000-0002-9694-4924
}
Konstantinos Malafantis. National and Kapodistrian University of Athens, Greece. kmalafantis@uoa.gr
https://orcid.org/0000-0001-5888-5719

\begin{abstract}
This study focuses on the countercultural comic book adaptations of the Odyssey. Since ancient Greek literature in general and Homer in particular, transcended the institutionalized formalistic and idealistic approach, the epics' adaptations became a vehicle for criticism or even a mirror of each receiving culture's present. The kind of relation established between each adaptation and its pre-text is defined by the inscribed meta-narratives in its body. The graphic adaptations under discussion, countercultural, demystifying or even subversive, participate in the so-called "cross-audience phenomenon", addressing a dual readership, both children and adults. They aim at undermining the heroic ethos, provoking skepticism and criticizing allusively contemporary politics. They also trivialize the original through humorous, satiric or ironic imitation. This way they facilitate dialogue between past and present, by creating a threshold, a contact zone within which pluralism is the major trait.
\end{abstract}

Key words: The Odyssey, classics' reception, comic book adaptations, threshold literature, pluralism

\section{Resumen}

Este estudio se centra en algunas adaptaciones no convencionales de la Odisea homérica en el cómic. Desde que la antigua literatura griega en general y Homero en particular, transcendieron la interpretación formalista e idealista, las adaptaciones épicas sirvieron como vehículo para la crítica o incluso como un espejo del presente de cada cultura receptora. El tipo de relación establecida entre cada adaptación y su pre-texto está definido por las meta-narrativas inscritas en su interior. Las 
adaptaciones gráficas que se discuten aquí, contraculturales, desmistificadoras o incluso subversivas, participan en el llamado "fenómeno de audiencias cruzadas", dirigiéndose a un lector dual, tanto niños como adultos. Su objetivo es socavar el espíritu heroico, provocar escepticismo y criticar de manera alusiva a la política contemporánea. También trivializan el original mediante imitaciones humorísticas, satíricas o irónicas. De esta manera, facilitan el diálogo entre el pasado y el presente, creando un umbral, una zona de contacto dentro de la cual el pluralismo es el rasgo principal.

Palabras clave: La Odisea, recepción de clásicos, adaptaciones de cómics, literatura de umbral, pluralismo.

\section{Resum}

Aquest estudi focalitza en algunes adaptacions no convencionals de l'Odissea homèrica al còmic. Des que l'antiga literatura grega en general i Homer en particular van transcendir la interpretació formalista i idealista, les adaptacions èpiques van servir com a vehicle per a la crítica o fins i tot com a un espill del present de cada cultura receptora. El tipus de relació establerta entre cada adaptació i el seu pretext està definit per les metanarratives inscrites al seu interior. Les adaptacions gràfiques que es discuteixen ací, contraculturals, desmitificadores o fins i tot subversives, participen en l'anomenat "fenomen d'audiències creuades", tot adreçant-se a un lector dual, tant infants com adults. El seu objectiu és soscavar l'esperit heroic, provocar escepticisme i criticar de manera al-lusiva la política contemporània. També trivialitzen l'original mitjançant imitacions humorístiques, satíriques o iròniques. D'aquesta manera, faciliten el diàleg entre el passat i el present tot creant un llindar, una zona de contacte dins de la qual el pluralisme n'és el tret principal.

Paraules clau: l'Odissea, recepció de clàssics, adaptacions de còmics, literatura de llindar, pluralisme.

\section{Introduction}

'Everyone who now reads and writes in the West, in whatever racial background, sex or ideological camp is still a son or daughter of Homer'. This is how Harold Bloom (1975, p.33) attempted to capture the place of Homer in modern society. Nevertheless, 'the cultural tradition is a continual re-selection of ancestors' (Williams, 2001, p. 68) whose paradigm and work may be adjusted and interpreted in order to serve present-day interests.

As Terry Eagleton (1983, p.10-11) says: "The fact that we always interpret literary works to some extent in the light of our own concerns [...] might be one reason why certain works of literature seem to retain their value across the centuries. [.....] 'Our' Homer is not identical with the Homer of the Middle Ages, nor 'our' Shakespeare with that of his contemporaries; it is rather that different historical periods have constructed a 'different' Homer and Shakespeare for their own purposes".

The Odyssey has almost uninterruptedly been selected but also reinterpreted by each receiving culture. Even more, when adjusted to children's cultural field it has proved itself

When the Odyssey and graphic language collide, they create unexpected variations of the ancient material, reflecting the receiving culture's practices and beliefs or the audiences' expectations. a crucial repository of humanist ideology and moralizing lessons. 
Homer, in education, has for a long time been cast in the mold of the political interests and social issues of each practicing culture, usually resulting in a stagnant and formalistic institutional approach, mainly serving nationalistic aims (Moula, 2012a). On the other hand, the adaptations of the Odyssey into new stories and various media since the 1970's, compose a prolific cultural field (Moula, 2012b), among which comics and graphic novels have a prominent place. So, when the Odyssey and graphic language collide, they create unexpected variations of the ancient material, reflecting the receiving culture's practices and beliefs or the audiences' expectations.

\section{Greek Classics' heritage and Homer in education and children's literature}

Ancient Greek literature, having survived through the centuries, consists incontestably a cultural capital of overriding importance for the global community. Since antiquity, the discourse of the 'classical' has functioned in just this way, to legitimate a social order and a set of institutions, beliefs, and values (Syropoulos, 2018), thanks to the permeability of the texts from the social and political timeliness. In the modern era, ancient Greece used to provide idealized virtues and ideological alibi for western civilization (Schein, 2011, p.75-85) 'Writing about Greece was in part a way for the Victorians to write about themselves' (Turner, 1981, p.8). Greece signified the values that were embraced by the intellectual genteel lifestyle. Hellenism practiced in England and Germany, as understood in the early nineteenth century, was used as a cornerstone of the ideological construction of stable or defensive nationalism (Stray, 1998, p. 23). In modern Greece also, Hellenism imbued the intellectual scene, especially from the $1880 \mathrm{~s}$ to the $1960 \mathrm{~s}$ and became the backbone of the nation-state ideal standard. The Nobel laureates, George Seferis and Odysseus Elytis, both incorporated ancient texts and Homeric allusions in their poetry, in effort to prove Greek poetry's natural continuity to its cultural heritage and to galvanize the modern national identity (Leontis, 1995).

Among ancient Greek literature, Homer occupies a distinguished position. Greece, "our mother," according to Hugo, is the "Grèce d'Homère"

This imperious authority of the 'classical' has been inextricably linked to the educational use of certain texts -among which Homer- as models of language and style and even more as the basis of educational and moral formation. because it was through ancient Greek poetry, especially the epics of the blind bard, that Hugo and his contemporaries would approach and understand the past (Rossell, 2011, p.81).

This imperious authority of the 'classical' has been inextricably linked to the educational use of certain texts among which Homer- as models of language and style and even more as the basis of educational and moral formation.

Europeans studied the "original" texts of the Greeks and "often spent numerous hours laboriously learning classical Greek yearning to discover the "real" Athens and Sparta". (Rossell, 2011, p.43). In pursuit of the meaning of the sacred ancient scripts, formalism became the lingua franca of the educational, academic (Highet, 1985, p.490-500) and artistic approach. The conservative classicist model adhered to the letter and ignored the spirit of the ancient works, attributing them an essentialist inherent meaning. 
In children's literature field, although Homer was considered to be the quintessence of poetry itself, he was mainly transmodalized from poetry to prose fiction (see the famous Tales from Troy and Greece of Andrew Lang, published in 1907).

In the famous poem of Hans Christian Andersen, A rose from Homer's grave, Homer is characterized as the greatest singer in the world.

For about a century (1876-1970) the Homeric myth in Greek children's books had been used as the essential carrier of ancient Greek spirit, reflecting the self-representations of each receiving society and it had been turned into a determinant factor of moral and national consciousness of the young recipients (Kalliakatsou, 2006).

Besides, the numerous editions of Homer for children, had to do with the necessity of acquainting young people with the ancient sources that influenced and shaped European culture.

Graphic narrative first undertook the risk to transfer Homer into a radical new form, that of comics, through the worldwide well-known series of Classics Illustrated. Classics Illustrated, when first published in the 1940's, comprised a novelty in the field of children's culture and offered an alternative to traditional and old-fashioned educative methods (Scarpelos, 2000, p.169), aspiring to educate and entertain at the same time. Nevertheless, they still adhered to and resounded the original script to guarantee gaining prestige.

The oft-repeated charge that comics would replace the classics in young readers' lives was counterbalanced by the exhortation that concluded each issue: "Now that you have read the C.I. edition, don't miss the added enjoyment of reading the original, obtainable at your school or public library" (Versaci, 2007, p.186).

In the ensuing years, many other graphic works moved along the same line. A work of similar potential is the Italian Odissea of Nizzi and Pifaerio: the characters' names are all Latinized (Ulysses, Jupiter, Juno instead of Odysseus, Zeus, Hera, etc.), the language is very literary and hypotactic - and therefore hardly suited for comic books, and the account of the facts follows the Homeric narration pedantically. The ad usum Delphini style of this work is evident in its manifest exaltation of good feelings, and the censorship of sexuality and violence.

Another, more recent but similar example is Marvel Illustrated: the Odyssey. Although grafted into the tropes and physiques of superhero comics, still claims its educative potential, through the use of a pseudo-Shakespearean kind of English, the information provided in recurring passages (The story so far, The Acheans, The Trojans) and the glossary at the end of each narrative.

\subsection{From Classical Reception to Adaptation Studies}

After the substantial notion of a self-reproducing high-brow literary tradition has been overcome, criticism and literary research shed light on the relationships of production and reception, which explain the expectations horizon's change in the process of aesthetic experience (Jauss, 1984, p.38).

Under this theoretical umbrella, it was realized that Homer's mega-text had traveled through time, place and languages and had shaped and communicated new stories introducing 
"dialogically radical ways with both pasts and presents" (Hardwick, 2007, p.52). As a result of this, but also in the light of anti-colonial movement a new critical field, Classical Receptions, emerged to explore the images and memories of ancient Greece and Rome as they have been exploited in later cultures.

One major field of interest in Classical Reception Studies consists of the Classics' transformations and adaptations and their underlying ideological discourse, articulated in the latent metanarrative of the text. A meta-narrative consists of the historically bound, inscribed and embedded in the body of the narrative, implicit ideological interpolations (Stephens \& Mc Callum, 1998, p.9). Adaptation as a phenomenon has been theoretically approached by several different angles (Diamantopoulou \& Stoikou, 2015). Genette examined thoroughly the phenomenon of transtextuality in general and hypertextuality $(1997$, p.4) in particular, which latter term overlaps in many aspects with adaptation. Hutcheon argues that one can define adaptation both as a product and as a process, in other words, as creative reinterpretation and palimpsestic intertextuality. An emphasis on process allows us to expand the traditional focus of adaptation studies on medium-specificity (Hutcheon, 2012, p.22).

Regarding medium-specificity, in the beginning, Adaptation Studies focused on the transcoding of a novel to a film. Wagner distinguishes three modes of this kind of adaptation as follows: transposition, commentary and analogy (Wagner, 1975, p.222-227). In transposition "a novel is directly given on the screen, with the minimum of apparent interference"; commentary is "where an original is... altered in some respect", revealing "a different intention on the part of the film-maker, rather than an infidelity or outright violation"; while an analogy takes "a fiction as a point of departure" and therefore "cannot be indicted as a violation of a literary original since the director has not attempted (or has only minimally attempted) to reproduce the original".

To highlight another significant dimension of the phenomenon of adaptation, James Naremore emphasizes the need for adaptation studies to definitely move away from formalistic concerns and study adaptations in the light of contextual (economic, cultural, political, commercial, industrial, educational) and intertextual factors (Naremore, 2000, pp.1-16).

Within this field, the adaptations of Homer's raw material into new graphic stories since the 1970 's, although they emanate from the firm belief of the ancient texts' supremacy, uncontested significance and guarantied popularity, yet, at the same time they cannot help but reflect the moment of their creation. The comic book adaptations of the Odyssey under discussion belong either to the category of commentaries or of analogies, represent the field of threshold literature (Gillian, 1997; Beckett, 1999, p.13-31) and are addressed to a dual audience (Beckett, 1999, xiii).

\section{The adaptations}

\subsection{Alternative- underground adaptations criticizing heroic ethos and contemporary politics}


As already discussed in brief, the underground comic book scene was the avant-garde of the 1970's (Hatfield, 2005, p.ix). They departed from the familiar, anodyne conventions of the commercial comics mainstream and upgraded comics to a means of artistic exploration and selfexpression. In the 1980's France was the undisputed leader in producing artistic comics, such as Metal Hurlant (1975) and À Suivre (1978). Heavy Metal, the American version of Metal Hurlant was a blend of American countercultural impulses (Zipes, 2006, p.177) and French Academic revolt of the 60s, but was primarily known for its depictions of the curvaceous female bodies in various states of undress (Jenkins, 2011, p.221). All three following creators, who used the Odyssey as the canvas of their innovative texts, pumped their arguments from the same counter-cultural field and have consequently much in common. They all had, at least once, collaborated with Heavy Metal magazine, which until today resounds the already established in the 70s underground impulses.

Although being distinct works, George Pichard's and As already discussed in brief, the underground comic book scene was the avant-garde of the 1970's [...] They departed from the familiar, anodyne conventions of the commercial comics mainstream and upgraded comics to a means of artistic exploration and selfexpression. Jacques Lob's Ulysses, Navarro's and Sauri's The Odyssey and Milo Manara's The Odyssey of Giuseppe Bergman, managed to arrive at a similar underground-friendly ethos, transforming the Odyssey either into a fantastically erotic voyage through a mid-life crisis (and the Odyssey), or into a journey into self-understanding culminated in the maturation of the hero (Giuseppe Bergman). In two of the works (Ulysses and Bergman) the reference to drugs makes a common denominator, either in order to rationalize magic or in order to criticize contemporary sub-cultures. Desirable callipygian women, always revealing without being obscene, surround the heroes during their adventures, while the lack of a concrete closure in all three adaptations admits of myriad interpretive possibilities.

George Pichard and Jacques Lob's Ulysses first appeared in 1968 in the Italian magazine Linus, which was culturally influenced by the French comic scene. Ulysses was several times revised (in France and Spain) until 1978, when published in Heavy Metal and in 1991, when reproduced for the series Eurotica. Nowadays it is available in two volumes. The adaptation mixes together elements from sci-fi, fantasy and druggie-porn, in adjusting to Metal Hurlant's initial intention (Screech, 2005, p.117). It reformulates the epic episodes and demonstrates such structural changes that revise the whole project. It drops most of the domestic scenes of the epic (included in the first eight rhapsodies) and leaps directly into Ulysses' adventurous return from Troy, during which Ulysses experiences psychedelic sex and drugs and participates in orgies. These experiences are to blame for his incapability to maintain an erection with Penelope, when back in Ithaca. Nevertheless, Penelope blames herself for not being able to live up to his erotic expectations. So Ulysses leaves Ithaca once again to seek new erotic worlds, showing that marital fidelity and domestic happiness constitute 'the oddest Odyssey of all' (Jenkins, 2011, p.235). On a visual level, we could claim that in a sense it adopts a pop art attitude, evident in the striking use of saturated, vivid colors that cover all possible space and the black outlines that underline the contrasting combinations, challenging traditions of fine art. At the same time the curvy outlines and the strong contrast of the colors are reminiscent of the 'psychedelic artwork 
-typically LSD-inspired patterns' in swirling glittering colors, which reveal the connection of the artist with the underground culture (Sabin, 1993, p.211).

An Odyssey of similar counter-cultural discourse is the one by Navarro and Sauri. It was inked in Spain in 1979-1982 and first published in Heavy Metal magazine in 1983. The adaptation's main intention is to be detached from the original, by creating an aesthetic- artistic effect that will raise it to the status of a self-contained cultural product. The black and white illustration and the realistic modality of the design contribute to this. The unique combination of the underground tradition to present nudity audaciously with the subtlety and the grace of its artistry in the Odyssey under discussion, place this work within the field of alternative comics, the more artistically ambitious comics of the 80s (Sabin 1993: 94-5). Besides, Heavy Metal in the mid-80ies began to feature more avant-garde European and American material, even if it still regularly featured semi-naked women in the cover to appeal to its traditional readership (Sabin, 1993, p.269, note 17).

Sauri's thorough investigation of the past captures myriad classical details from ancient amphorae and urns to architecture and scripts, as well as elements from Renaissance, Baroque and art nouveau (Jenkins, 2011, p.221-235). However, his classical ethos is counterbalanced by the introduction of a visual counter text to the original script, which subverts the traditional reading of the Odyssey and replaces it by a version, more compatible with the contemporary modern way of thinking. No linear unfolding of the events is to be found and the distortions or modifications of the myth emphasize on the erotic-sensual not to say hedonistic sides of Ulysses' travel. A female universe sets the coordinates of his adventures and surrounds him affectionately and protectively. Kalypso gives birth to two Ulysses' children and is presented as a faithful wife in love. Circe holds him passionately and tenderly, though Nausicaa admires him secretly. The supernatural interventions are omitted and the whole story takes place on a secular level exclusively. Without sliding to melodramatics, the text could be classified as a romance rather than an epic. The author hypersexualizes Ulysses' journey, so that the ideal of marriage and monogamy, as presented in Homer, seems to be an anguishing perspective, which signals middle-age crisis. The reunion of Penelope with Ulysses does not seem to be the 'telos', the endpoint of the version. The last long-distance shot (Kress \& Van Leeuwen, 1996, p.126-131) of the couple detaches the viewer from the happy and highly expected reunion motif, creates an alienating effect and degrades the significance of the meeting, leaving the reader with an open ending. Navarro's sexual politics diverge from the classical reception, though in a more judicious way than that of Picahard's.

The third adaptation of the same category is Milo Manara's The Odyssey of Giuseppe Bergman. Manara was among the many famous artists who welcomed French influences and the artisticunderground trend. (Booker, 2010, p.390). The Italian comic book writer and artist was best known for his 'exquisitely-drawn sex-erotica albums' (Sabin, 1993, p.195). With his artistic roots in the cultural milieu of the underground comics, he never betrayed his origin and became a landmark of the field with his characteristic elegant, beautiful women caught up in unlikely and imaginary erotic scenarios.

The first adventure of Bergman, the protagonist of this extraordinary Odyssey, was originally serialized in the legendary comics magazine À Suivre, beginning in 1978. 
Bergman, a dissatisfied 20-something longing for adventure, responds to the invitation of some mysterious companionship and travels to the Mediterranean. So, he repeats the journey of Ulysses on a literal and spiritual level, only to reach some critical points of self-understanding and to judge reality, by expressing some indisputable truths about humanity. Themes of responsibility and human nature run through the story. By choosing Elpenor who had had the most disgraceful anti-heroic death in Odyssey as Bergman's main interlocutor, Manara, sets an alternative, demythologizing point of viewing and commenting on the epic facts. At the end of the adventures, on the verge of fantasy and reality, Bergman seems more mature and conscious of human condition. He denounces injustice, hypocrisy, lack of democracy, human arrogance and cruelty, environmental degradation, wars, the immorality of the powerful, etc criticizing in a poignant way society's ills. He concludes that only love can counterbalance the insanity of the world, which repeats unabatedly the same fatal mistakes that lead to its self-destruction. His preferred Ithaca is in the loving and attractive arms of the lady-skipper.

A humorous, distant analogy of Odyssey is Bodyssey by Corben and Revelstoke. The alliteration of Odyssey in Bodyssey suffices to recall the mythical adventure storyline and to classify this comic book within the range of the subverting, sacrilegious adaptations of the epic (Booker, 2010, p.505). Before Corben and Revelstoke made the full feature-length story, they had published several short story versions, with the

And although the creators often update the Homeric characters' motivations and actions with a more contemporary sensibility, they adhere fairly closely to the ancient epic's narrative and even -though to a lesser extent- its ethos. The heroes, nevertheless, are not so glamorous and even Helen of Troy, old and decadent, is not the immaculate beauty she used to be adventures of Pilgor, the humorous fake Greek hero. Pilgor had appeared in various independent editions until Bodyssey finally became a continuous narrative and ran as a comic series in Heavy Metal magazine in 1985. Catalan Communications published a collected edition the following year. Bodyssey's connection with Heavy Metal places it within the intellectual environment of underground comix, a relationship that becomes tangible in the spicy illustrations and the ithyphallic symbolism. Bodyssey's characters were less Greek and more critically satirical of the popular barbarian heroes since the story employed a futuristic sci-fi scenario in an epic adventure of perpetual gaffes on the magical planet.

\subsection{Generating skepticism: adaptations as critical lenses of the present}

Odysseus the Rebel, Steven Grant and Scott Bieser's 2009 graphic novel version of Homer's The Odyssey, dutifully pays credence to the ancient epic in its depiction of Ulysses as a storytelling survivor who encounters various gods, witches, monsters, and peoples in his long journey home to Ithaca. And although the creators often update the Homeric characters' motivations and actions with a more contemporary sensibility, they adhere fairly closely to the ancient epic's narrative and even -though to a lesser extent- its ethos. The heroes, nevertheless, are not so glamorous and even Helen of Troy, old and decadent, is not the immaculate beauty she used to be (figure 1). Certain alterations in the story e.g. Hades presented as a modern metropolis (figure 2), submit a critic to the contemporary world and foster reflection about the ancient world's values and myths. Women and lesser characters obtain a voice and judge the male-centered 
male-dominated society and injustice. Ulysses challenges the Gods and his return home is rather problematic. After having fulfilled his destiny, he departs once again, exactly as the mythological tradition wanted him to. His unappeased passion for adventure made his long-desired return just a transitional stage in his life-long adventures. On a visual level, the clear-cut black and white drawings reveal an artistic preference for minimal effects and transpose the metacenter of the adaptation in its underlying ideological discourse. The metanarrative of this Odyssey generates skepticism and ambiguity instead of certainty and compliance with the epic's heroic ethos.

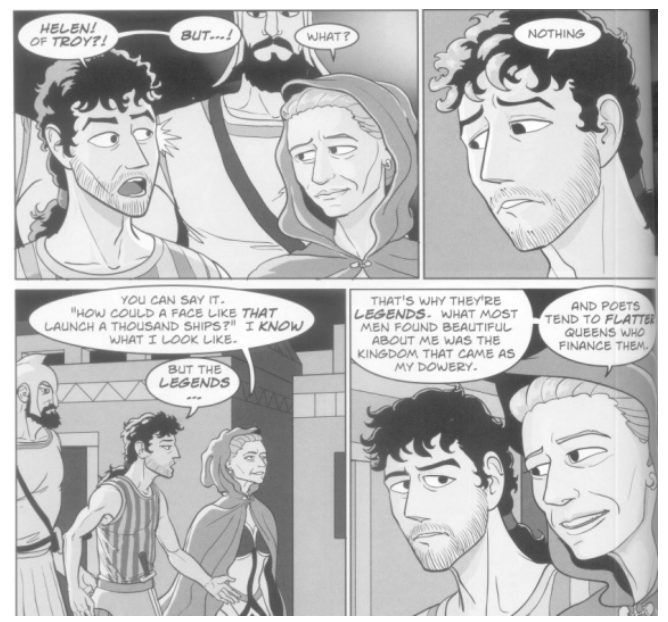

Figure 1. Odysseus the Rebel, (Grant and Bieser, 2009)

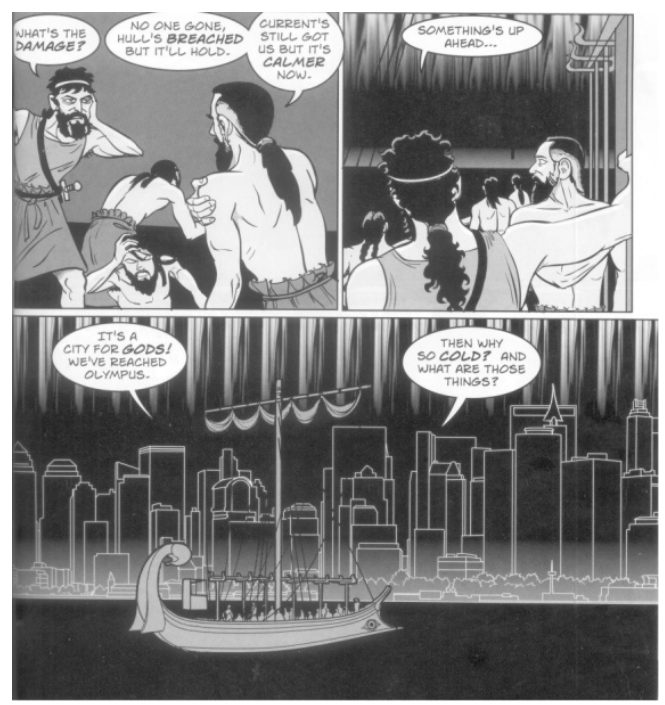

Figure 2. Odysseus the Rebel, (Grant and Bieser, 2009)

Infinite Horizon (2011), an allusive adaptation of The Odyssey, takes place in a not-too-distant future in which an even bigger part of the Middle East has become a war zone, and China is 
shooting down American satellites. In the heart of this living hell the U.S. army hero, 'The Captain', is striving to survive and even save his small group of abandoned soldiers home. They cross almost half the globe, low on supplies and hope and endure deadly encounters with many enemies, including the Cyclops, and the Sirens.

Back at home, Penelope is having her own apocalypse-oriented problems, trying to defend their water supplies. Homer's original or, for those not so familiar with ancient Greek myth, any postArmageddon drama, can both be considered as its source. This adaptation, between Homer's classic epic and popular culture's conventions, blends both traditions so as to appeal to contemporary audiences' taste. The recontextualization of ancient myths within new settings has always been a widespread practice in the course of cultural evolution, while the exploitation of the Odyssey's adventure structure in popular media, in particular, has been a common practice in the cultural production of our time (see the movies: Oh brother where art thou? by the Cohen Brothers (2000) or the Usual suspects by Bryan Singer (1995)). The adaptation, following this trend, places itself in the field of the Odyssey's analogies, that disguises contemporary anxieties into ancient myths.

\subsection{Undermining heroism and provoking laughter through compositional choices and metafictional devices}

Among the main categories of intertextuality (Wilkie, 1996, p.181), one can find texts of imitation which seek to parody, imitate the style, interpret, or supplant the original and even to undermine the de facto prestige of great writers of the past. Parody and pastiche (Genette, 1997, p.89),-meaning a medley of various ingredients, a hotchpotch- are key attributes of postmodern culture. They both contest classics' authority and insurmountable excellence and their irreverence submits a two-sided critic, both on past and present. At the same time and ever since literary criticism introduced a more flexible approach towards classics, they were cast into various aesthetic and interpretative molds and were exploited in prolific intertextual ways.

Marcia Williams' The lliad and the Odyssey (1996) is made

They both contest classics' authority and insurmountable excellence and their irreverence submits a twosided critic, both on past and present. At the same time and ever since literary criticism introduced a more flexible approach towards classics, they were cast into various aesthetic and interpretative molds and were exploited in

prolific intertextual ways. of this quality. It balances on the verge of pastiche and parody. Without becoming incoherent, Williams' sharp-eyed look grasps myriads of details. These could otherwise distract the reader if it were not for her ability to counterbalance this diffusion with the centripetal written narrative. Her abundant creativity and natural proclivity to humor is expressed by the numerous titillating minor details which surround the main narrative and are scattered carelessly all over the panel surface, creating an interpretative net of their own (figure 3). Nevertheless, she manages to transform a pastiche-like synthesis into a multidimensional parody: of styles, of epic ethos and even of our present. 


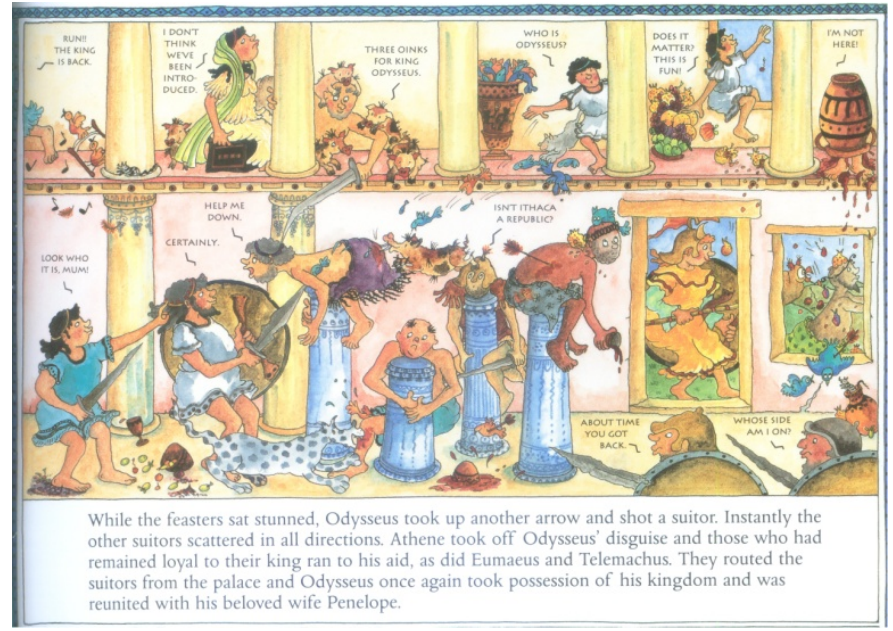

Figure 3. The Iliad and the Odyssey (Williams 1996)

Since parody lies in the idea of a norm and the sense of mockery and laughter at the abnormal, Williams succeeds in transplanting and therefore parodying the 'high-brow' Homeric norm into the cartoon tradition. One could also claim that Williams' Odyssey is a simulacrum of Homer's Odyssey which reflects the subversive and revisionary potential of our critical era. Williams puts forward a literal comic adaptation which subverts the established sobriety of the educational approach. The major element of her Odyssey is that it exploits 'format as signifier in itself' (Hartfield, 2005, p.52), taking advantage of the compositional meaning's resources: informational value, framing and salience and modality as well as of the visual codification's potential, by choosing the sensory one (Jewitt \& Oyama, 2001, p.151).

When an element is placed on the upper part of the visual synthesis, it is presented as ideologically superior and when at the bottom as real (Kress \& Van Leeuwen, 1996, p.186-193). Placing the humorous visual version of the classic text above the text itself, Marcia Williams gives priority to its informational value and this way she subverts the traditional high toned and serious approach of Homer's texts and establishes new humoristic ones.

In the same vein, a similar effect is achieved in Ulysses' Odyssey with his partner Karagiozis by Giokas (1999). The mingling of heroes and the transposition of them into a different place or time (Rodari, 1994, p.186-190) is a genuine source of incongruous and thus hilarious situations. To a certain point, this could be paralleled to Fredric Jameson's (1994) description of postmodernity, where space replaces time in the way we understand the world. On the unspecified space of 'Greece', an imaginary chronotope with emphasis on topos, time zones merge and create a unified and unique moment, when ancient Greek glory and present-day marginal status of Greece converge and co-exist. This extraordinary meeting of Ulysses and Karagiozis reflects the schizophrenic dualism of Greek national identity, tracing its roots to the colonial European thinking (Bozatzis, 1999). Ulysses and Karagiozis represent West and East and this way they combine the celebrated past and the inglorious present of Greece.

Karagiozis, a popular and funny figure of the common cultural background of many countries, who, trying to make ends meet, is inexhaustible in contriving and getting into trouble, becomes the alter ego of the resourceful and ingenious Ulysses with whom he shares his long journey back to Ithaca. Being present at both extra-diegetic and diegetic level, he narrates the story from 
his point of view, interchanging from being homodiegetic to autodiegetic narrator (Fridaki, 2005, p.148-149). The diegetic level may be defined and framed by the paratextual present of the act of the narrative, or on the contrary, the extradiegetic level may be considered as the main narrative in which Odyssey is embedded (figure 4). The adaptation shows a different intention on the part of its creator, rather than an infidelity or outright violation. Following the script closely, it diverges from it only to provoke laughter through Karagiozis' comic presence.

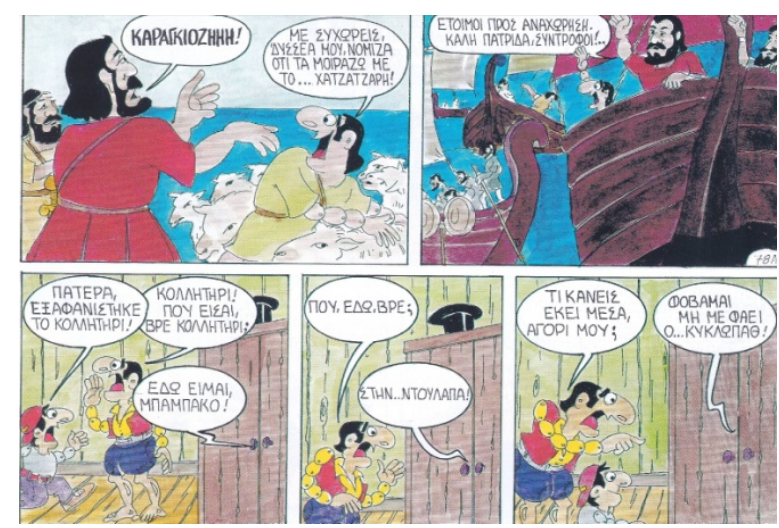

Figure 4. Ulysses' Odyssey with his partner Karagiozis (Giokas 1999)

A one of a kind case of a comic book adaptation of the Odyssey is the coup d' etat in Ithaca by Kyr (1977). This parody of the Odyssey is a cultural product of the change of polity period in Greece after the overthrow of the Junta (1967-1974) (Soloup, 2012, p.205-208). Kyr had earlier started to publish a serialized Odyssey in the magazine Eikones (Images), but it was censored and prohibited by the junta. The coup d' etat in Ithaca was published in 1977 as part of an album titled Pyr (meaning Fire). Through an allegorical and satirical code, it reflects and criticizes the political situation in Greece, commenting on its dreary past and its promising, but not yet fulfilled present. It is a groundbreaking innovation since it initiated the prolific field of political comic scene which flourished the following years and even more. It took advantage of certain techniques and conventions that had first appeared in the alternative comic scene (like selfreferentiality and play within a play). The story subverts and derides not only the Homeric myth, the heroic ideal and the illusion of Greece's regeneration after the reinstatement of democracy but also the conventions of the comic book medium, through the use of metafictional devices (Waugh, 1984, p.2) and the merging of the narrative levels.

What we read is supposed to be a theatrical performance by famous comic book protagonists playing the roles of the mythical figures, on a play based on the Homeric script. During the performance, the actors go on strike because of the killing of one of them by Polyphemus. They demand better working conditions and ask for higher wages (figure 5). To exercise pressure and achieve their goals, they publish their independent comic book. This fact recalls a big strike of the Greek journalists in 1975 and the publication of their journal, called Independent Opinion. The artist himself participates in the story and persuades the actors to come back by promising them to comply with the terms of their contracts, but in the end, he scuttles the boat they have embarked on, after having conceded to give them a raise. Ulysses alludes to Konstantinos Karamanlis, Greek prime minister of the period, the suitors to Papadopoulos and the rest of the 
colonels, Phaeacia to France, the land of Karamanlis self-exile during the junta, Scylla and Charybdis to CIA and ESA (Greek secret services) and so on. The slogan 'Ithaca belongs to pagan Ithacans' resounds the Junta's slogan 'Greece belongs to Christian Greeks' and the Trojans' protest against the Greeks with the slogan 'Greeks go home' has its homologous in the Greek postulation: 'Americans go home'.

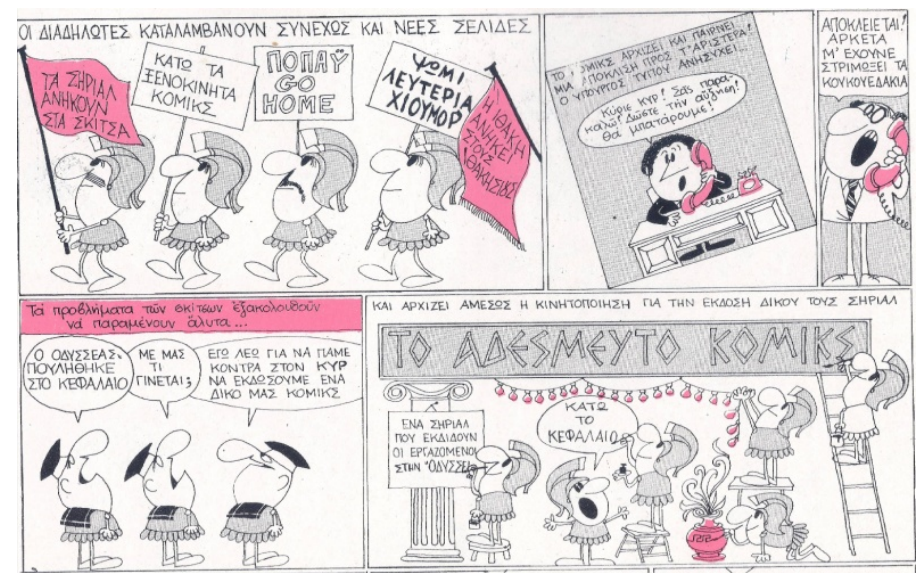

Figure 5. Pyr (Kyr, 1977)

The long-lasting controversy between Greece and Turkey about Aegean sea tidelands is implied by the quarrel of the two supposed to be God Neptune, the Greek, and the Turk, who both assert their originality. The statue of Liberty stands for mythical Circe, who allures and transforms unsuspecting Greeks into pigs- slaves (figure 6). This Odyssey is a comprehensive mirror of Greece in the mid-70s in almost every political, cultural, ideological and social aspect, while it is at the same time, both a genuinely amusing and also a thought-provoking comic book.

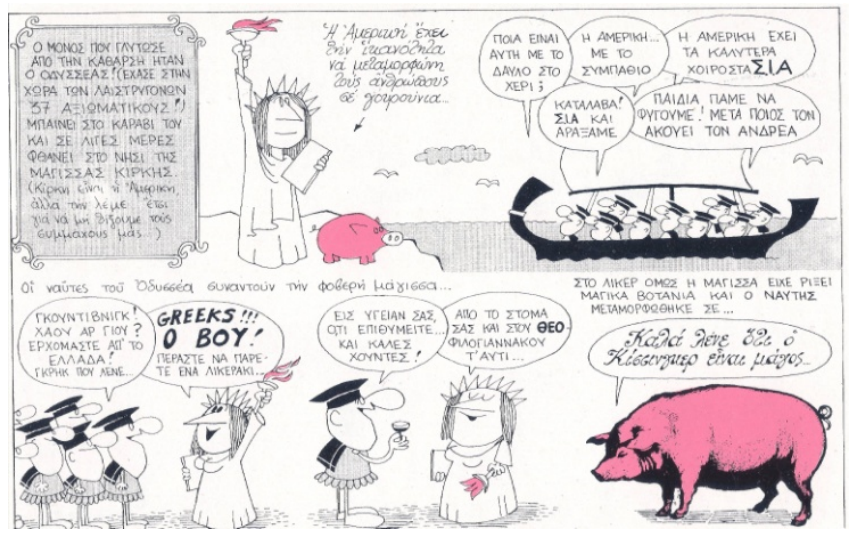

Figure 6. Pyr (Kyr, 1977)

3.4. An embedded Odyssey, intertextual references and thematic fission of the Odyssey in a graphic novel

Fun Home by Alison Bechdel (2006), a graphic memoir focusing on the protagonist's complex relationship with her father and addressing themes of sexual identity, gender stereotypes, suicide, and family life, also promotes the determinant role of literature in understanding oneself. Within this specter, the Odyssey is used as an axis around which the major daughterfather relationship revolves and is explained, the allusive lens (Chute, 2006) through which 
incidents are presented, as retold in the light of new information (e.g. the class of Joyce's Ulysses). The protagonist's subjective Odyssey is embedded (p.202-220) as Homeric references are scattered and diffused in the main body of the narrative and create a discontinuous but coherent allegorical rereading of the epic. It is an Odyssey narrated by the protagonist -a Telemachus' female counterpart-point of view, as long as it is experienced and revived through her consciousness. This gradually unfolding personal Odyssey of the protagonist becomes the canvas on which the plot is weaved, by offering all the necessary figures of speech and explanatory frames for the crux of the narrative. Let's have a quick look at this interplay between Homer's Odyssey and that of Alison.

When she was a student, she had to choose a course on Joyce for the January term at the University, due to her previous negligence, she thought of it as a sort of divine intervention of a similar kind of Goddess Athena's intervention to Telemachus, as long as The Portrait of an artist had always been her father's favorite. This random choice of hers would be the starting point of the long journey to discover herself and her father: 'she embarked on an Odyssey, consisting as it did, in a gradual episodic and inevitable convergence with her abstracted father and nearly an epic as the original...' (p.202). When she makes these thoughts, the background wall is decorated by a painting of John Flaxman, titled 'The descent of Athena'.

A wordplay allows her to parallel Paris, Helen's of Troy supposed legendary lover and Paris (the French capital), where Colette, the author, spent her life according to her autobiography. 'Paris plays a similarly inciting role in my Odyssey too', she thought. The parallelism-game becomes even more elaborated when, attending a class about Joyce's Ulysses, she and her classmate are asked to find correspondences between the Odyssey and Joyce's Ulysses, which she finds unnecessary and boring. To her opinion "without the Homeric clues, Ulysses would certainly be unreadable". She could not find any interest in these classes because "her own Odyssey was calling so seductively. One siren led to another in an intertextual progression'. Everything resonates and reflects the Odyssey. Even May Sarton's book that she read, was titled 'Mrs. Stephens hears the mermaids singing'. When she was basking in Colette's sensualism, she felt like the sea-ravaged Ulysses had once felt, 'in the ministrations of Nausicaa'. And even further 'like Ulysses' men who had fallen in with the lotus-eaters', she felt no urgency to continue, with her class.

The trepidation, not to say repulsion she felt when she first visited the Gay Union is compared to Ulysses' feelings during his descent into the Underworld. This fact made her conscious of having lain between the Scylla of her peers and the swirling sucking Charybdis of her family (p.213). Her first sexual intercourse with a woman was with a one-eyed girl, who she compares with Polyphemus (figure 7). On the contrary to Ulysses though, she did not desperately try to escape but wished to be able to stay there forever (p.214). Her mother, like Ulysses' wife, faithful Penelope, had 'kept the household going for 20 years with a more or less absent husband' (p.16). 


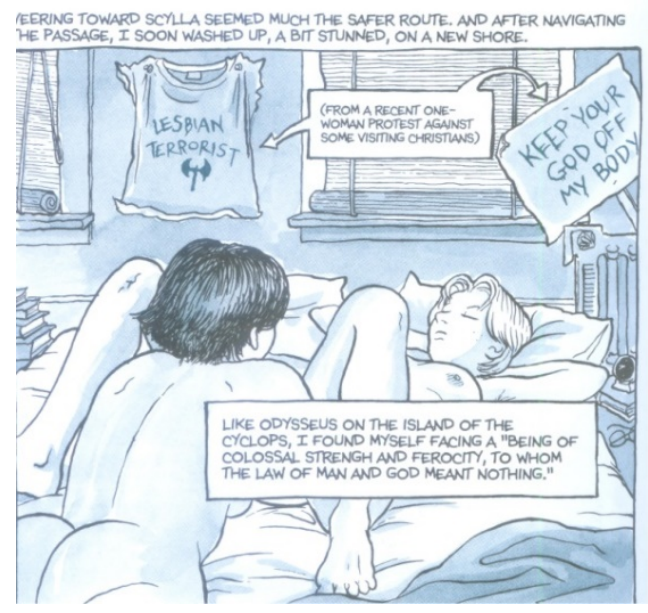

Figure 8. Fun home (Bechdel 2006)

When in the end, daughter and father reveal straightforwardly each other their secrets, 'it was not the sobbing, joyous reunion of Ulysses and

It is noticeable that the Odyssey colonizes the western imagination while each thematic component of it is being harnessed multidimensionally as a motif in different contexts. Telemachus. It was more like fatherless Stephen and sonless Bloom from Joyce's Ulysses". Nevertheless, on a backdrop shaped by a page from the same novel, in the embedded caption of her thoughts, she reaches the climax of her personal Odyssey, by declaring: 'We had had our moment of Ithaca'!

It is noticeable that the Odyssey colonizes the western imagination while each thematic component of it is being harnessed multidimensionally as a motif in different contexts.

\section{Conclusions}

The graphic narrative (Moula \& Christodoulidou, 2018) whenever appropriates a classical text and in particular the Odyssey, challenges, re-evaluates, and questions the distinction between high and low brow culture (Versaci, 2001, p.61-67) and the very concept of literature's supremacy over other narrative arts. As long as classical texts' comic book adaptations are cultural practices, they need to be approached as acts of discourse, partaking of a particular era's cultural and aesthetic needs and pressures. Such adaptations bridge the gap between the past and the present and immerse classical tradition into each receiving culture's Zeitgeist. When the Odyssey's adaptations revisit, comment on or diverge from the classical texts, to incite reflection or provoke humor, they offer the reader a critical lens to apply to present-day reality.

Adaptations which distance themselves from the original are situated within the epistemological frame of classics' reception and adaptation studies, which demolished the once existent hierarchies and debunked classics' political agenda. Since classics are not handled as holy scriptures anymore, the adaptors feel free to improvise and above all, to use the Odyssey as a vehicle for criticism or as a mirror of their society.

The underground sub-cultural current in the comics field, part of a more generalized movement against the status quo and its adult-orientated publications, subverted the educationally driven 
values of the theretofore Odyssey's conventional readings, by adopting, adapting and reorganizing sings of the dominant interpretation, in order to manufacture new meanings that appeal to contemporary audiences.

This tendency sometimes is expressed through adaptations that aim at undermining the heroic ethos, provoke skepticism and criticize allusively contemporary politics. Other times adaptations trivialize the original by using humorous, satiric or ironic imitation and facilitate dialogue between past and present, by creating a contact zone (Pratt 1999) of pluralism, within which several contrapuntal voices can be heard.

To conclude with, comic books' adaptations of the Odyssey compose a wide and miscellaneous promising field, in constant interweaving with the cultural milieu. Divergent or subversive adaptations generate a counter-hegemonic discourse, having to do with the cultural context of their production and also with their dual target audience, which influences in a determinant way the outcome.

\section{References}

Adams, G. (1997). Moving Thresholds, Expanding Genres. Children's Literature, 25(1), 233-239.

Beckett, S. L. (1999). Transcending Boundaries: Writing for a Dual Audience of Children and Adults. NY and London: Routledge.

Bloom, H. (1975). A Map of Misreading. Oxford and New York: Oxford University Press.

Booker, K. M. (2010). Encyclopedia of Comic Books and Graphic Novels. Santa Barbara, California: Greenwood.

Bozatzis, N. (1999). Greek National Identity in Talk: A Rhetorical Articulation of an Ideological Dilemma. Unpublished doctoral thesis. Lancaster University. Retrieved from: https://bit.ly/2RkgaGS.

Chute, H. (2006). Gothic Revival. The Village Voice (July 11, 2006). Retrieved from: https://www.villagevoice.com/2006/07/04/gothic-revival-2/

Diamantopoulou,L. \& Stoikou, Z. (2015). Cavafy reanimated: Intermedial transformations in comics and animation. Journal of Greek Media \& Culture, 1 (2), 299-319, doi: 10.1386/jgmc.1.2.299_1

Eagleton, T. (1983). Literary Theory: An Introduction. Minneapolis: University of Minnesota Press.

Fox, A. \& Hwang-Eschelbacher H. S. (2016). Classical Symbolism in Asterios Polyp. In G. Kovacs \& C. W. Marshall (Eds.). Son of Classics and Comics (pp.47-66). Oxford and New York: Oxford University Press.

Fridaki, E. (2005). The Theory of Narrative in the Teaching Practice. Athens: Kritiki.

Genette, G. (1982). Palimpsestes. La littérature au Second Degré, Paris: Seuil. Rpt In G. Genette, (1997). Palimpsests: Literature in the Second Degree. trans. Channa Newmanand Claude Doubinsky, Lincoln: University of Nebraska Press.

Hardwick, L. \& Stray Ch. (Eds.) (2008). A Companion to Classical Receptions. Oxford: Blackwell publishing.

Hardwick L. (2007). Singing across the faultlines. Cultural shifts in twentieth-century receptions of Homer. In B. Graziosi \& E. Greenwood (Eds.) (2007). Homer in the Twentieth Century: Between World Literature and the Western Canon (pp.47-73). Oxford University Press. 
Hatfield, Ch. (2005). An art of tensions: The otherness of comics reading. In Alternative Ccomics: An Emerging Literature (pp.32-67). Jackson: University Press of Mississippi,

Highet, G. (1949). The Classical Tradition: Greek and Roman influences on Western literature. Oxford: Clarendon Press. Rpt In Highet, G. (1985). The Classical Tradition: Greek and Roman influences on Western literature. N.Y. and Oxford: Oxford University Press.

Hutcheon, L. (2012). A theory of Adaptation. New York: Routledge.

Jenkins, E. T. (2011). Heavy Metal Homer. Countercultural appropriations of the Odyssey in graphic novels. In G. Kovacs \& C. W. Marshall (eds.). Classics and Comics (pp. 221-235). Oxford-N.Y: Oxford University Press.

Jewitt, C. \& Oyama R. (2001). Visual meaning: A social semiotic approach'. In Th. V. Leeuwen and C. Jewitt. L.A. (eds.) (2001). Handbook of Visual Analysis. (pp. 134-156). London, New Delhi, Singapore, Washington: Sage.

Kalliakatsou I. (2006). Aspects of the Antiquity in the Books of Childhood. The Paradigm of Homeric Myth. Unpublished doctoral thesis. University of the Aegean. Faculty of Humanities. Department of Preschool Education and Educational Design. Rhodes. (in Greek)

Kress, G. \& Leeuwen Th.V. (1996). Reading Images. The Grammar of Visual Design. London and New York: Routledge.

Leontis, A. (1995). Topographies of Hellenism: Mapping the homeland. Ithaka, N.Y: Cornell University Press.

Lewis, C. S. (1961). An Experiment in Criticism. Cambridge: Cambridge University Press.

Lodge, D. \& Wood N. (eds.) (2000). Modern Criticism and Theory: A Reader. Pearson: Harlow.

Marshall, C. W., \& Kovacs, G. (eds.) (2009). Classics and Comics. Oxford University Press.

Marshall C. W. (2015). Odysseus and The Infinite Horizon. In G.Kovacs \& C. W Marshall. (Eds.) (2015). Son of Classics and Comics (pp.3-32). Oxford, UK: Oxford University Press.

Moula, E. (2012a). Greek Classics through Comic Books: Negotiating cultural tradition under the fidelity pseudo-dilemma. Journal of Literature and Art Studies, June 2 (6), 587-605.

Moula, E. (2012b). The Odyssey through modern cultural "texts" and their educational use. Cinema and comics at the service of Homer's critical reception and of our epoch. Proceedings of the 6th Panhellenic Conference of the Hellenic Institute of Applied Pedagogy and Education, Athens, 57/10/2012 (in Greek). Retrieved http://www.elliepek.gr/documents/6o synedrio eisigiseis/26 Moula.pdf

Moula E., Christodoulidou L. (2018). Graphic narrative: Critical literary and self-referential framing of the field. Keimena, v.26, January (in Greek). Retrieved from: https://bit.ly/2qrbLqD

Naremore, J. (2001). 'Introduction: Film and the Reign of Adaptation. In Naremore, J. (Ed.) Film Adaptation. (pp. 1- 16). London: Athlone.

Pratt, M. L. (1999). 'Arts of Contact Zone'. In Bartholomae D. and Petroksky A. (eds). Ways of Reading. (5th ed). New York: Bedford/St. Martin's. Retrieved from: https://bit.ly/38c7sR5

Rodari, G. (1994). Grammar of imagination. Athens: Tekmirio.

Scarpelos, J. (2000). Historical memory and Greekness in comics. Athens: Kritiki. (in Greek).

Schein, S. L. (1999). Cultural Studies in Classics. In T. Falkner, N. Felson N. \& D. Konstan (Eds.) Contextualizing Classics: Ideology, Performance, Dialogue, Lanham MD: Rowman. 
Schein, Seth L. (2008). Our Debt to Greece and Rome: Canon, Class and Ideology. In L. Hardwick, \& C. Stray (eds.) (2011). A Companion to Classical Receptions. (pp.75-85). Blackwell Publishing.

Screech, M., (2005). Masters of the Ninth Art: Bandes dessinees and Franco-Belgian Identity. Liverpool: Liverpool University Press.

Soloup. (2012). Greek Comics, Athens: Topos.

Stephens, J. \& Mc Callum, R. (1998). Retelling Stories, Framing Culture: Traditional Story and Metanarratives in Children's Literature. New York and London: Garland Publishing.

Stray, C. (1998). Classics Transformed: Schools, Universities, and Society in England, 1830-1960. Oxford: Clarendon.

Syropoulos, S. (2018). Past as Political Data. Myth and historical tradition in the political thought of Ancient Greece. Athens: Gutenberg (in Greek).

Turner, F. M. (1981). The Greek Heritage in Victorian Britain. New Haven: Yale UP.

Versaci, R. (2001). How comic books can change the way our students see literature: One teachers perspective. English Journal, 91: (2), 61-67.

Versaci, R. (2007). This Book Contains Graphic Language. Comics as Literature. N.Y.- London: Continuum.

Wagner, G. (1975). The Novel and the Cinema. Rutheford, Madison and Teaneck: Farleigh Dickinson University Press.

Waugh, P. (1984). Metafiction: the Theory and Practice of Self-conscious Fiction. London: Methuen.

Wilkie, C. (1996). Intertextuality. In P. Hunt (Ed.) International Companion Encyclopedia of Children's Literature. London and New York: Routledge.

Williams, R. (1961). The Long Revolution, Canada: Broadview Press.

Wright, B. (2001). Comic Book Nation: The Transformation of Youth Culture in America. Baltimore: The Johns Hopkins University Press.

Zipes, J. (1983). Fairy Tales and the Art of Subversion: The Classical Genre for Children and the Process of Civilization. New York: Methuen.

\section{Works cited}

Bechdel, A. (2006). Fun Home, US: Houghton Mifflin (hardcover); Mariner Books (paperback).

Duggan, G. \&Noto P. (2011). Infinite Horizon. Image comics.

Giokas, P.(1999). Ulysses' Odyssey with his partner Karagiozis. (4 issues). Athens: Dardanos (in Greek). Grant, S. \& Bieser S. (2009). Odysseus the Rebel. Bighead Press.

Kyr (1977). Pyr. Athens: Grigoris (in Greek).

Lang, A., \& Ford, H. J. (2006). Tales of Troy and Greece. Courier Corporation. (1907 1st edition)

Lob, J. \& Pichard G. (1968) Ulysses. Linus, trans. in eng. by Sean Kelly and Valerie Marchant (2006).

Manara, M. (2003). The Odyssey of Giuseppe Bergman.US: Humanoids Publishing.

Marvel Comics. Odyssey, (8 vol) 2008.

Navarro, F. \& Sauri J. M. (2005). The Odyssey. Heavy Metal Classics. 
Nizzi C. \& P. Piffarerio (1990). Le avventure di Ulisse a fumetti. San Paolo

Reyelstroke, S. and Corben R. (1986). The Bodyssey. Catalan Com.

Williams, M. (1996). The Iliad and The Odyssey. London: Walker Books Ltd.

How to cite this paper:

Moula, E. \& Malafantis, K. (2019). Homer's Odyssey: from classical poetry to threshold graph-ic narratives for dual readership. Journal of Literary Education, (2), pp. 52-70. doi: 10.7203/JLE.2.13779 